\title{
Amy Bock
}

\section{and the western tradition of passing women}

\section{JOHANNA MARY}

Johanna Mary is a Wellington writer. She held a PEN-Reader's Digest Fellowship at the Stout Research Centre in February-March 1994, to research cross-dressing women as background for a novel. This is an edited and abridged version of a seminar she gave at the Stout Research Centre on 27 July, 1994.

Amy Bock is popularly known as a Victorian/Edwardian con artist. She's famous for disguising herself as a man and marrying a woman. This exploit was presented in the media as an outrageous anomaly, deserving the most sensational attention. But in fact when Bock disguised herself

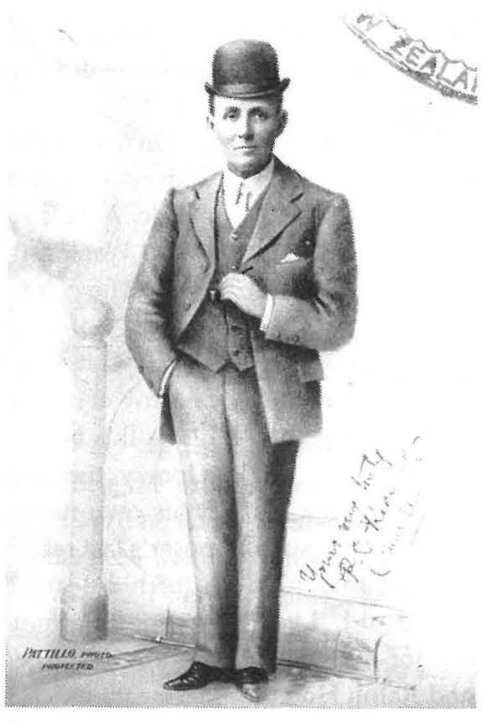
as a man she was part of a tradition that stretches back centuries.

When white settlers colonised New Zealand, one of the more underground and obscure traditions they brought was that of cross-dressing women. Women who disguised themselves as men, lived as men, and convinced the world that they were men. In current argot, they 'passed' as men. From now on, I'll call them 'passing women'.

We can get a fairly good idea of why some women took on a male role. Some motives crop up time and time again: to work as a man and receive male rates of pay; to escape the restrictions and poor status of a female life; to fight a war; to marry or form a romantic relationship with another woman; to join a male lover who has gone to sea or to war; to escape from a hated husband or parent; for safety when travelling; as a criminal disguise; and finally what would today be called transsexualism, or gender dysphoria. Some women seem to have genuinely felt they should have been men or actually were men.

What linked all these women was the tradition, passed down through the centuries. Most passing women had heard of others who'd done so. Many had been told about passing women by friends, had heard them sung about in ballads and folk songs, or read about them in books. The tradition gave them an answer to their problems. The knowledge that other women had passed often encouraged their own decision to do so.

To locate Amy Bock within the tradition of western passing women, I'm interested in three areas: motives for the disguise, mechanics of the disguise, and public reaction to it. But first the story of her masquerade. This is a potted version of the article which was in the Otago Daily Times soon after her arrest:

In January 1909, Amy Bock took a job as housekeeper in Roslyn, Dunedin. The family left her in charge while they went on holiday. She then pawned their furniture and disappeared. The police could find no trace. A few days later, a small man in a grey suit, with luggage including a dress basket, came to the door of a boarding house in York Place. His name was Percy Redwood, and he needed accommodation. He said he was a clerk, holidaying because of ill-health. He had a warm, generous personality and soon became popular with the landlady and all the boarders. He seemed well-off, and spent money lavishly.

After three weeks he visited Port Molyneux, where he said his aunt lived. He asked his landlady to save his room while he was gone, as some relatives and friends would soon be in Dunedin and might want it. He left behind the dress basket, saying it contained clothes belonging to his aunt. After a week he returned, the victim of a catastrophe. He said he'd been fishing and, while hauling in a large

OPPOSITE: While masquerading as Percy Redwood, Amy Bock had a professional photographer take some portraits of her. When the media storm over the masquerade blew up, the photographer-Cecil Wright Pattillo-moved swiftly to copyright them.

ABOVE: One of the many postcards that were sold to capitalise on interest in Bock's masquerade. 
groper, had accidentally let his pocketbook fall from his coat into the water. It sunk, containing all his cash. $\mathrm{He}^{\prime} \mathrm{d}$ found a diver who would recover it, but only for cash up front. So the landlady's sister lent him $£ 41$ - all her savings.

Percy returned to Port Molyneux, where he boarded at the house of a respected family the Ottaways. Debonair, welldressed, the son of a wealthy mother in Hamilton, Percy was liked by everyone. He courted the Ottaways' daughter Agnes, and proposed. Agnes accepted.

Mrs Ottaway received letters from Percy's mother confirming his good background and financial status, and saying she and Percy's brothers and sisters would attend the wedding. Preparations began and Percy used further clever ruses to borrow more money from various sources. But soon his many creditors started to check up on him and become anxious. By 20 April, the eve of his wedding, he was barely managing to placate them. The big day dawned. Many guests arrived, including the local MP. A lavish feast had been prepared, and the ceremony was to be elaborate.

But where was Percy Redwood's family? Percy said he couldn't understand it, but perhaps it was because his sister was getting married in Auckland the same day, and his relatives had decided to go to her wedding instead. Someone stood in for his brother as groomsman, and the ceremony proceeded. Sure enough a letter of apology from Percy's mother was later read out, confirming Percy's explanation. But guests were now talking, comparing notes about their experiences with Percy Redwood. They were gossiping about his debts, wondering about the absence of his rich family, and becoming suspicious.

After the wedding the Ottaways, also apprehensive, challenged Percy as to his monetary resources. He said his mother would be there in a week, and would sort out all his financial problems. So the Ottaways gave him a week's grace. He was to stay in Port Molyneux, and, until he paid his debts, ' his wife would be a wife in name only'.

Meanwhile two of Percy's acquaintances discovered that the address he'd given for his mother was fraudulent. Then, enquiring about possessions he left at his last boarding house, they found that the dress basket included hair cut from a woman's head. They told the police.

The Otago Daily Times concluded its story in true Sherlock Holmes style:

'By Jove!' suddenly cried Detective Hunt, 'I wonder if it's Amy!'

'I believe it is', said Detective Herbert.

... Detective Hunt drove to Port Molyneux.... Mr Redwood was called and came down the stairs coolly smoking a pipe. Detective Hunt and the long-lost and much-wanted Amy Bock were not by any means unknown to each other.

'The game's up, Amy', said the officer.

Amy Bock had probably heard of other passing women. Perhaps they influenced her decision to pass. Newspapers in 1909 speculated wildly over her motives. New Zealand Truth reported that several years earlier Bock was a friend and patron of Pollard's Juvenile Opera Company. Truth said it was probably seeing how well the girls in the company acted boy parts that gave Bock the idea of donning male attire.

It was also reported that Bock had once said she was tired of defrauding men, as they were too easy, whereas women were much harder to deceive. The papers inferred that the novelty of deceiving one of her own sex into a marriage ceremony very much appealed to her.

A Mrs Buxton, at whose place Bock stayed in 1902, seven years before her masquerade, told a story which was then reported in the Otago Witness of 5 May 1909. She and Bock were in town one evening, when Bock saw a man's ready-made suit in a shop window, of a size that would just about fit her. She told Mrs Buxton a heart-rending story about a poor youth in Invercargill who needed such a suit. She said it was just about the right size for him, and wanted to buy it.

The implication is that Bock was fabricating the story of the poor youth. It certainly sounds like one of these, which were full of poor, luckless people she wanted to help out. If Mrs Buxton's anecdote is true, it suggests that Bock had at least considered passing as a man, years before her stint as Percy Redwood.

A combination of motives is possible for Bock's masquerade. The most obvious is criminal disguise. She was already a convicted criminal who had used 
aliases and disguises (previously all female). This must have facilitated her decision to pass. We can also guess that she enjoyed living with male privileges and independence. And she apparently had relationships with women. In her book Out Front Julie Glamuzina says that later in her life Amy Bock lived with a woman for many years. Although I don't think wanting to have a relationship with a woman was one of Amy Bock's main reasons for disguise, it may have contributed, and an attraction to women probably made her disguise easier.

How did Bock and others pass as men? Many women looked younger dressed as men. Bock seems to have been no exception. At the time of her masquerade she was 48 years old. However, the certificate of marriage between Percy Redwood and Agnes Ottaway gives Redwood's age as 30 .

The Dunedin Evening Star noted Bock's male appearance:

... A front view showed a diminutive man, welldressed, neat of limb, with neater feet, and rather goodlooking ... She seemed to be holding the coat close to herself, as if to hide her figure. Her face was neat, rather than pretty ... A back view made it almost impossible to believe that the little man between the detectives was a woman ... She walked with the slight stoop of the scholar, but with a firm tread. Her build was quite ordinary to anyone who did not know the truth, when one knew the facts, there were obvious peculiarities. The back of her head was a man's, from the back rim of a light-coloured cap placed jauntily on the head to the collar of the overcoat, her hair was shorn like that of a guardsman on parade.... Her walk was not womanly, which must not be taken as having anything to do with decorum. Most men know how women walk, and this woman walked more like a man fond of easy-fitting trousers. Altogether, one could easily understand why women have been deceived by this woman. As showing how men were deceived, it is interesting to mention that the bridegroom was measured and suited at the New Zealand Clothing Factory, and although her petite form required nothing more than size $131 / 2$ for collars and shirts, no one suspected anything 'amiss.' Not even the measurer.

Some passing women took on exaggeratedly macho personas. Bock didn't. As Percy Redwood she was gentle and kind. Many reported that Percy Redwood was effeminate, but hardly any suspected that he was actually a woman. He said he had bad health.
This apparently explained why for a man he was so frail looking, and soft spoken. It was also an excuse for him to avoid going outside. When he had to go into town a taxi chauffeured him everywhere, presumably so as he wouldn't run into anyone who might recognise him as Amy Bock.

No evidence suggests that Agnes Ottaway knew Percy was a woman. So how did Bock think she was going to keep convincing Ottaway she was a man after they were married and expected to sleep together? As mentioned, Percy wasn't allowed by $\mathrm{Mr}$ and $\mathrm{Mrs}$ Ottaway to.sleep with their daughter on the wedding night. Nonetheless I wonder how Amy Bock planned to cope. Historically some passing women married to other women who didn't know their secret feigned moodiness or illness to avoid sex. One used an old war injury as an excuse for years. Others have used dildoes.

Bock wasn't a drinker, but on her wedding day, as Percy Redwood, it's said she had seven whiskies and by the evening was quite drunk. Perhaps she thought this might relieve her of her conjugal duties. Or maybe she was going to use ill health as an excuse again. Evidence suggests that in any case she wasn't planning to stay with Agnes Ottaway long, and was in fact scheming to disappear within days.

Newspaper coverage of Amy Bock's masquerade was very sensational. Although she had a list of past convictions for false pretences and forgery dating from the 1880 s, and had sometimes made headlines, her masquerade as Percy Redwood brought her to a peak of notoriety.

During the month after her arrest, Amy Bock appeared in court in Dunedin four times, and the courtrooms overflowed. Newspapers nationwide reported the proceedings in detail. On days when she made. no court appearance, the press fed the public with details of her past exploits; or comment from people who knew her as Percy Redwood. Local businesses also capitalised. Only days after her arrest, bookstalls advertised 'Amy Bock and Percy Carol Redwood postcards'. These featured bridegroom photos

ABOVE: This portrait photograph by $\mathrm{Mr}$ Pattillo is believed to have been for Agnes Ottaway's locket. 
of Percy Redwood, and facsimiles of some of Bock's forged letters On 21 May, one paper ran this odd little advertisement: 'AMY BOCK would be delighted with a cup of our tea. Usual price $2 \mathrm{~s}-$ now $1 \mathrm{~s} 1 \mathrm{~d}$.At Escott's, 119 George Street, Dunedin'.

On 15 May, an advertisement in the 'Sales by Auction' section of the Otago Daily Times trumpeted: Monday 17th May, At 1 o'clock sharp.

THE AMY BOCK alias PERCY CAROL REDWOOD JEWELLERY AND PRESENTS THE WEDDING CAKE, Etc.,

JAMES SAMSON \& CO have been instructed to sell by auction, at their Rooms, Dowling street, The

large and valuable collection of high-class Goods.

These included Agnes Ottaway's wedding and engagement ring, all the wedding gifts, Percy Redwood's bridegroom suit, even the ornaments from the wedding cake.

The auction took place. A reporter on the same paper wrote on 18 May 1909 :

... It was truly a wonderful crowd: Old folks hobbling on sticks; little folks losing themselves amid a forest of legs; women, young, old, middle-aged and otherwise ... An observant spectator would seldom see the same face twice, for crowd relieved crowd, earnest and intent, and wholly fascinated, reminiscent of the pictures one sees of an execution at Newgate ...

... The things were costly and handsome enough, but an atmosphere of meanness was over them all, and they lay bizarre and pathetic symbols of a cruel sacrilege before a crowd packed from wall to wall, devouring them with hungry eyes, tittering and applauding as the bids rose shilling by shilling ...

On 27 May, Amy Bock made her final court appearance for this case, and was sentenced to two years' hard labour. On 17 June, the press reported the annulment of her marriage to Agnes Ottaway, and, finally, Amy Bock was old news.

'News' can be defined as an incident which disturbs or challenges the way we think things are or should be. So it makes sense that passing women are big news. They represent disorder in a fundamental way. They challenge a basic distinction in our society - that between male and female.

However, any lesbian connotations to Amy Bock's courting of and marriage to Agnes Ottaway were either ignored by the press, or never considered. The only possible mention was in Truth on 8 May 1909, which called Bock 'perhaps perverted'. It's hard to know exactly what knowledge and attitudes regarding sex were then current in New Zealand. Certainly overseas the work of the sexologists was gaining popular currency. If people did suspect sexual motives on Bock's part, it was perhaps out of respect for Agnes Ottaway that they didn't mention it, she being generally considered a poor victim of the cunning and heartless Bock. Also, 'respectable' newspapers didn't talk about sexual matters. The only paper I have come across that did, was Truth, which touted itself as a moral crusader daring to say what other newspapers didn't. In referring to the 'sham' marriage of Amy Bock and Agnes Ottaway, they treated the idea of marriage between two women simply as ridiculous.

I believe there's also another reason for fascination with Bock's exploits, and that's the intriguing personality of Bock herself. In 1909, debates raged over whether she was a heartless con-artist, or a pitiable victim of a lifelong mental illness - kleptomania. Bock herself was the originator of the kleptomania theory. At her court trials over the years she had consistently pleaded insanity. She played to the hilt the faint, sickly, fragile woman the Victorians prized as a feminine ideal. Maybe this image didn't often gain Bock lighter sentences, but it won her some public sympathy.

But Bock's crimes seemed to belie fragility. She proved herself daring, resourceful, and robust. I think this is another reason for her popularity. In some press descriptions there's more than a hint of admiration. Her expertise in forgery is praised, her almost foolproof male impersonation marvelled at. She's 'brilliant'. Her face is 'that of the accomplished actress'. An ex-policeman, who had dealt with her in the past, said 'She is very clever, and, in my opinion, would make an exceptional novel writer'.

Sometimes there is a fine line between criminal and hero. Bock was a rebel. She played with people's expectations and then confounded them. She never stayed in one town long and moved between false identities easily. Maybe many of us have a secret desire to experience this kind of freedom. And of course, although most reports of Amy Bock are written by men, we can guess that for many women of the era, the power and freedom Bock had gained by male disguise had great appeal.

\section{SELECTED BIBLIOGRAPHY}

Baynes, Sylvia. Transvestism and the Advancement of Women. The Minorities Trust, 1989.

Dekker, Rudolf, and van de Pol, Lotte. The Tradition of Female Transvestism in Early Modern Europe. Macmillan Press, 1989.

Dugaw, Dianne. Warrior Women and Popular Balladry 1650-1850. Cambridge University Press, 1989.

Robson, R W. 'The Adventures of Amy Bock'. Otago Daily Times 1909. The San Francisco Lesbian and Gay History Project. "She Even Chewed Tobacco": A Pictorial Narrative of Passing Women in America'. In Duberman, Vicinus, and Chauncey (eds). Hidden From History - Reclaiming the Gay and Lesbian Past, NAL Books, 1989.

Wheelwright, Julie. Amazons and Military Maids. Pandora, 1989. 